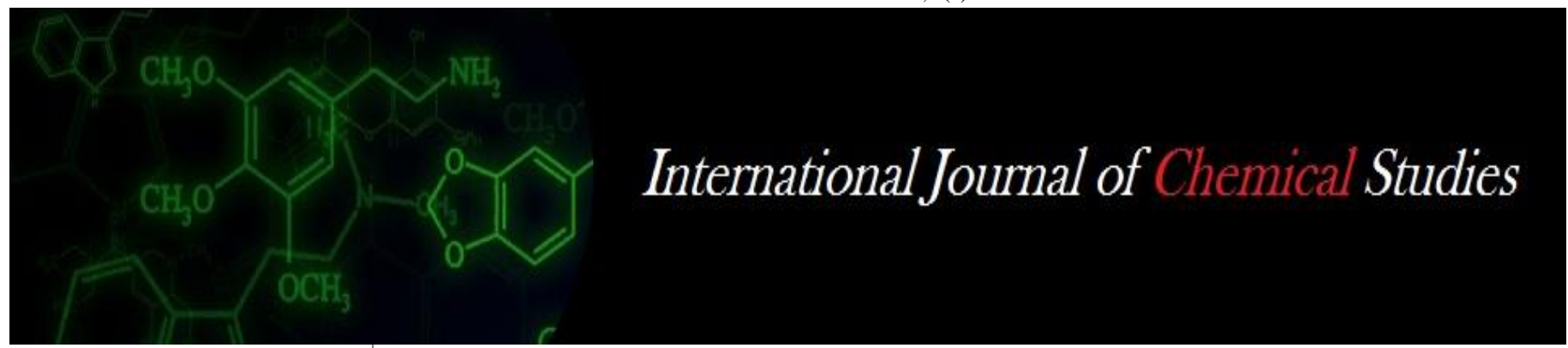

P-ISSN: 2349-8528

E-ISSN: 2321-4902

IJCS 2020; 8(1): 524-528

(C) 2020 IJCS

Received: 04-11-2019

Accepted: 06-12-2019

\section{Giri PR}

Ph.D. Scholar, Department of Agricultural Extension and

Communication, Post Graduate Institute, MPKV, Rahuri,

Maharashtra, India

\section{Chavai AM}

Assistant Professor, Department of Agricultural Extension and Communication, Post Graduate Institute, MPKV, Rahuri,

Maharashtra, India

Chougule SB ${ }^{3}$

Ph.D. Scholar, Department of Agricultural Extension and Communication, Post Graduate Institute, MPKV, Rahuri, Maharashtra, India

\section{Corresponding Author:}

Giri PR

Ph.D. Scholar, Department of Agricultural Extension and Communication, Post Graduate Institute, MPKV, Rahuri, Maharashtra, India

\section{Entrepreneurial behaviour of sugarcane juice centre owners: A qualitative approach}

\author{
Giri PR, Chavai AM and Chougule SB
}

DOI: https://doi.org/10.22271/chemi.2020.v8.i1h.8312

\begin{abstract}
An experiment entitled "Entrepreneurial behaviour of sugarcane juice centre owners" was conducted at Department of Extension Education, Post Graduate Institute, MPKV, Rahuri, during 2016-17. The study was conducted with a sample size of 110 from Tehsil Rahuri District Ahmednagar, respectively. The results of the present study revealed that the 70.00 per cent of the respondents belongs to medium entrepreneurial behaviour category. Whereas, 16.36 per cent and 13.64 per cent belongs to low and high entrepreneurial behaviour category. On the other hand, entrepreneurial behaviour characteristics such as innovativeness was medium i.e.,71.82 per cent in Sugarcane juice centre owners. Among all 55.45 per cent of respondents were medium achievement motivation, 50 per cent of the respondents were moderate in decision making ability. The 56.36 per cent respondent belongs to medium economic motivation, 57.27 per cent of the respondents were medium risk orientation, respectively. The majority of the respondents result were exhibited medium level of entrepreneurial behaviour, while very few of them exhibited high level of entrepreneurial behaviour. The characteristics such as education, annual income, family size, marketing behaviour, source of information were positive and found significantly positive relationship with entrepreneurial behaviour. Age, land holding and area under crop were not significantly related with entrepreneurial behaviour of sugarcane juice centre owners. The studied characteristics in sugarcane juice centre owners are responsible for better economic growth and increase in employment.
\end{abstract}

Keywords: Entrepreneurial behaviour, juice centre, sugarcane, innovativeness

\section{Introduction}

The entrepreneurship is necessary for the development of any nation. In the rapid growing world, every country tries to achieve high socio-economic development for the prosperity of the society and betterment of its people. Any society is made up of both male and female gender. So, the contribution of both men and women in economic activities is very much important for a healthy nation building. An entrepreneur is one who organizes, operates and assumes the risk in a business venture in an expectation of making profit. The word "Entrepreneur" came from French word "Entreprendre", which means "to undertake" or "to do something".

For the value addition to farmer products, there is need to promote entrepreneurship among farmers and development of small scale agrobased industries in the villages. The vital role played by the entrepreneurs in sharing the economic destiny of the nation. Sugarcane (Saccharum officinarum) is a high value and water-intensive commercial crop cultivated traditionally in most part of India. The major sugarcane growing states are Uttar Pradesh, Maharashtra, Tamil Nadu, Karnataka, Andra Pradesh and Gujrat. Maharashtra is one of the largest producer of sugar contribute about 34.00 per cent of sugar in the country followed by Uttar Pradesh. The general Area of Sugarcane in Maharashtra is 6.20 lakh hectares with Production 372.40 lakh tonne and Productivity is 68.04 (t/ha), simultaneously sugarcane recovery is $11.24 \%$, respectively. (Anomy, 2017).

\section{Material and Methods}

The research was conducted in Ahmednagar district of Maharashtra state during year 2016-17. The Ahmednagar district has been purposively selected for the study because of the availability of sugarcane juice centre owners also as per convenience of the rsearcher with the study area. In Ahmednagar district Tehsil Rahuri is having maxium number of sugarcane juice 
centre owners and hence selected purposively as locale of the study. "Ex - post facto" research design was employed in the present research study as the events have already occurred. The data were collected by interviewing the sugarcane juice centre owners with the help of a pre-tested structured interview schedule developed for the purpose. The data collected from the respondents was scored, tabulated and analysed by using suitable statistical tools such as Frequency, Percentage, Mean and Standard deviation, respectively.

\section{Scoring and Categorization \\ Innovativeness}

Innovativeness is the degree to which an individual adopts new ideas relatively earlier than others in his social system. (Rogers and Svenning, 1969). Scale developed for measurement of innovativeness by Hurt, et al. (1977) was used for measurement of innovativeness of sugarcane juice centre owners.

This procedure contains statements regarding entrepreneurial qualities. The people respond to their environment in different ways. The scale consist of 12 statement and response obtained on five point continuum viz., 'Strongly agree', 'Agree', 'Neutral', 'Disagree' and 'Strongly disagree' and score of 'five', 'four', 'three', 'two' and 'one', respectively was assigned to each statement. There was no right or wrong answers, just asked to record the first impression.

Based on total score obtained by the respondent on innovativeness they were grouped into three categories. keeping the mean \pm standard deviation as check.

Table 1: Innovativeness

\begin{tabular}{|c|c|c|}
\hline Sr. No. & Category & Score \\
\hline 1 & Low & Up to 56 \\
\hline 2 & Medium & 57 to 64 \\
\hline 3 & High & 65 and above \\
\hline & Mean: 60.57 & S.D $: 04.38$ \\
\hline
\end{tabular}

\section{Achievement motivation}

It was operationalized as the desire for excellence to a sense of personal accomplishment. It was measured with the help of scale developed by Chandrapaul (1998) ${ }^{[3]}$.

The instrument consist of six statements and responses obtained on three point continuum viz., 'agree', 'undecided' and 'disagree'. A weightage of 3, 2, and 1, were assigned to the response categories in the positive statements and the scoring was reversed for negative statement. The total score of the respondents on their achievement motivation was arrived summing up the weightage responses for each statement. Thus, the total for each juice center owner on his achievement motivation ranged from 6 to 18. on the basis of total score obtained by respondents on achievement motivation, they were grouped into three categories keeping the mean \pm standard deviation as check.

Table 2: Achievement motivation

\begin{tabular}{|c|c|c|}
\hline Sr. No. & Category & Score \\
\hline 1 & Low & Up to 14 \\
\hline 2 & Medium & 15 to 16 \\
\hline 3 & High & 17 and above \\
\hline & Mean: 15.52 & S.D: 1.07 \\
\hline
\end{tabular}

\section{Decision making ability}

The decision-making ability of an individual may be defined as the ability to select the most efficient means among the available alternatives on the basis of scientific criteria for achieving the maximum economic profit. The instrument had eight decision criteria. The response categories for each item were 'not considered', 'considerd after consultation with others' and 'decision taken independently'; the response alternative was scored with 1,2 and 3 score respectively.

Thus, total scores for all the statements were obtained by adding all scores. Then the juice center owners were classified into three categories on the basis of mean \pm standard deviation as shown under.

Table 3: Decision making ability

\begin{tabular}{|c|c|c|}
\hline Sr. No. & Category & Score \\
\hline 1 & Poor & Up to 18 \\
\hline 2 & Moderate & 19 to 20 \\
\hline 3 & Good & 21 and above \\
\hline & Mean:19.57 & S.D: 1.12 \\
\hline
\end{tabular}

\section{Risk orientation}

Risk refers to the degree to which an entrepreneur is oriented towards risk and uncertainty in running the enterprise. The scale developed by Supe (1969) ${ }^{[17]}$ was used to measure the risk preference of the respondents.

The risk bearing ability with eight items was presented to the respondents on a 5-point continuum scale ranging from 'strongly agreed' to 'strongly disagreed' through 'agree', 'undecided' and 'disagreed'. The score assigned were 5, 4, 3, 2 and 1 respectively. The respondents were categorized on the basis of mean \pm standard deviation.

Table 4: Risk orientation

\begin{tabular}{|c|c|c|}
\hline Sr. No. & Category & Score \\
\hline 1 & Low & Up to 14 \\
\hline 2 & Medium & 15 to 16 \\
\hline 3 & High & 17 and above \\
\hline & Mean: 15.49 & S.D $: 1.20$ \\
\hline
\end{tabular}

\section{Economic motivation}

It is operationally defined as occupational success in terms of profit maximization and relative value that respondent's places on economic ends.

It was measured with the help of developed schedule. It consists of seven statements. It was measured in three point continuum as agree, undecided and disagree responses and it was scored as 3, 2 and 1, respectively. Whereas, reverse score was assigned for negative statement. The categorization was done as follows on the basis of mean \pm standard deviation.

Table 5: Economic motivation

\begin{tabular}{|c|c|c|}
\hline Sr. No. & Categories & Score \\
\hline 1 & Low & Up to 17 \\
\hline 2 & Medium & 18 to 19 \\
\hline 3 & High & 20 and above \\
\hline & Mean: 18.30 & S.D: 1.41 \\
\hline
\end{tabular}

\section{Overall entrepreneurial behaviour}

For the present study, entrepreneurial behaviour of sugarcane juice centre owner is operationally defined as cumulative outcome of five selected components of entrepreneurial behaviour viz., innovativeness, achievement motivation, decision making ability, economic motivation and risk orientation was measured.

Entrepreneurial behaviour was measured with the help of entrepreneurial behaviour index by addition of scores of five attributes namely innovativeness, achievement motivation, 
decision making ability, economic motivation and risk orientation. The total obtained score was converted into entrepreneurial behaviour index. The entrepreneurial behaviour index was calculated by the following formula.,

\section{Sum of obtained Score on five \\ $E B I=\frac{\text { entrepreneurial components }}{\text { Maxium obtainable Score }} \times 100$}

The respondents were classified into three categories viz., low, medium and high, respectively on the basis of equal interval method as given below.

Table 6: Entrepreneurial behaviour Index

\begin{tabular}{|c|c|c|}
\hline Sr. No. & $\begin{array}{c}\text { Entrepreneurial } \\
\text { behaviour level }\end{array}$ & $\begin{array}{c}\text { Entrepreneurial behaviour } \\
\text { Index Range }\end{array}$ \\
\hline 1 & Low & Up to 124 \\
\hline 2 & Medium & 125 to 134 \\
\hline 3 & High & 135 and above \\
\hline \multicolumn{2}{|c|}{ Mean: 129.47} & SD: 5.036 \\
\hline
\end{tabular}

\section{Results and Discussion}

The data revealed from the study shows that majority of the respondents were middle age (36 to 57 years). As regards the education, most of the respondents educated up to higher secondary level and most of the respondents belonged to family of small size (up to 5 members).

The majority of the respondents possessed marginal size ( $\mathrm{Up}$ to $1.00 \mathrm{ha})$ of land holding and half of the respondent possessed small (1.01 to $2.00 \mathrm{ha}$ ) land holding. The majority of the respondents were under medium annual income category (Rs. 92,596 to Rs. 2,69,045).

The majority of the respondents were engaged in juice centre as occupation. Majority of respondent had medium area under sugarcane crop. The medium respondents used sources of information for seeking information related to enterprise. Similar findings were reported by Bhagyalaxmi et al., Patel et al. (2003), Nagesha (2005), Shete (2008). Kumar et al., (2012) and Jayarani et al. (2013) ${ }^{[1,13,18,12,9]}$.
Overall entrepreneurial behaviour of sugarcane juice centre owners

The entrepreneurial behaviour of the sugarcane juice centre owners was studied. The data regarding the overall entrepreneurial behaviourof sugarcane juice centre owners were collected and analyzed. The result subsequently presented in Table 7.

Table 7: Distribution of the respondents according to their overall entrepreneurial behaviour

\begin{tabular}{|c|c|c|c|}
\hline \multirow{2}{*}{ Sr. No. } & \multirow{2}{*}{ Categories } & \multicolumn{2}{|c|}{ Respondents (N=110) } \\
\cline { 3 - 4 } & & Frequency & Percentage \\
\hline 1 & Low (up to 124 scores) & 18 & 16.36 \\
\hline 2 & Medium (125 to 134scores) & 77 & 70.00 \\
\hline 3 & High (134 and above scores) & 15 & 13.64 \\
\hline \multicolumn{2}{|c|}{ Total } & 110 & 100.00 \\
\hline
\end{tabular}

The data presented (Table 7) indicated that majority of the respondents had medium entrepreneurial behaviour category i.e., 70.00 per cent followed by 13.64 per cent and 16.36 per cent with low and high entrepreneurial behaviour respectively. Similar conformity results were found by Nagesha et. al (2011), Daya Ram and Chaudhary (2012) and Bourah (2015) ${ }^{[13,6,2]}$.

\section{Innovativeness}

It can be observed that the 71.82 per cent of the sugarcane juice centre owners belongs to medium innovativeness category (Table 8), followed by high (11.82\%) and low $(16.36 \%)$ category, respectively. The medium innovativeness of respondents might be due to fact that majority (47.27\%) of sugarcane juice centre owners were middle aged and belongs to medium decision making $(50.00 \%)$ in farming activities. All these factors might have contributed for their medium level of innovativeness. The results are in accordance with the findings of Bhagyalaxmi et al., (2003) and Wadekar (2016) ${ }^{[1,}$ 20].

Table 8: Distribution of respondents according to their entrepreneurial behaviour components

\begin{tabular}{|c|c|c|c|c|c|}
\hline Sr. No. & Characters & \multicolumn{2}{|c|}{ Categories } & Frequency & Percentage \\
\hline \multirow{4}{*}{1.} & \multirow{4}{*}{ Innovativeness } & Low & $(<56)$ & 18 & 16.36 \\
\hline & & Medium & $(57-64)$ & 79 & 71.82 \\
\hline & & High & $(>64)$ & 13 & 11.82 \\
\hline & & Mean $=60.57$ & $\mathrm{SD}=4.38$ & 110 & 100 \\
\hline \multirow{4}{*}{2.} & \multirow{4}{*}{ Achievement motivation } & Low & $(<14)$ & 24 & 21.81 \\
\hline & & Medium & $(15-16)$ & 61 & 55.45 \\
\hline & & High & $(>16)$ & 25 & 22.73 \\
\hline & & Mean $=15.52$ & $\mathrm{SD}=1.07$ & 110 & 100 \\
\hline \multirow{4}{*}{3.} & \multirow{4}{*}{$\begin{array}{l}\text { Decision making } \\
\text { Ability }\end{array}$} & Poor & $(<18)$ & 26 & 23.64 \\
\hline & & Moderate & $(19-20)$ & 55 & 50.00 \\
\hline & & Good & $(>20)$ & 29 & 26.36 \\
\hline & & Mean=19.57 & $\mathrm{SD}=1.12$ & 110 & 100 \\
\hline \multirow{4}{*}{4.} & \multirow{4}{*}{ Risk orientation } & Low & $(<14)$ & 24 & 21.81 \\
\hline & & Medium & $(15-16)$ & 63 & 57.27 \\
\hline & & High & $(>16)$ & 23 & 20.92 \\
\hline & & Mean $=15.49$ & $\mathrm{SD}=1.20$ & 110 & 100 \\
\hline \multirow{4}{*}{5.} & \multirow{4}{*}{ Economic Motivation } & Low & $(<17)$ & 25 & 22.72 \\
\hline & & Medium & $(18-19)$ & 62 & 56.36 \\
\hline & & High & $(>19)$ & 23 & 20.90 \\
\hline & & Mean $=18.30$ & $\mathrm{SD}=1.41$ & 110 & 100 \\
\hline
\end{tabular}

\section{Achievement motivation}

Achievement motivation is a psychological variable, which differs from one individual to another. It can be observed that
55.45 per cent respondents (Table 8) were found to have medium achievement motivation followed by 22.73 per cent respondents falling in the category of high achievement 
motivation, respectively. Among those 21.81 per cent had low achievement motivation. It is assumed that achievement motivation forces the individual towards reaching some goals, which he has set for himself/herself. This predominant medium motivation levels can be attributed to the social and economic status of a respondent, who fails to achieve greater goals. The findings are in line with studies conducted by Daya and Chaudhary (2012), Ghube (2014) and Keisham (2016) ${ }^{[6,}$ $7,10]$

\section{Decision making ability}

Decision-making is the act of choosing between two or more courses of action. In the wider process of problem solving, decision making involves choosing between possible solutions to a problem. Majority of the respondents has moderate decision-making ability 50.00 per cent, followed by respondents having good decision making ability 26.36 per cent and 23.64 per cent of respondents had poor decision making ability. (Table 8).

This was due to good amount of knowledge and information they have. They take decision taking their personal, social and business situation into account. The results of the study are in accordance with the findings of Sapam (2009), Jayarani (2013), Bourah (2015) ${ }^{[14,9,2]}$.

\section{Risk orientation}

Results revealed that the majority of the respondents 57.27 per cent were medium risk orientation followed by 21.81 per cent respondent having low risk orientation. The 20.92 per cent were found to have high risk orientation (Table 8), respectively. Good level of risk orientation was due to younger age, good education and better economic condition of the respondents. This shows that, they do not avoid risks and at the same time, simulteniously they dont like situations and commitments where the chances of desired outcome is very low. To be a successful entrepreneur, one has to take calculated risk at times. The findings of the study are in line with the studies of Bhagyalaxmi et al., (2003), Suresh (2004), Nagesh et.al (2011), Thakare ( 2013) and Wadekar (2016) ${ }^{[1,}$ $16,13,19,20]$.

\section{Economic motivation}

The economic motivation is the process of stimulating people actions to accomplish the goals. In the work goal context the psychological factors stimulating the people's behaviour can be desire for money. It was observed from the data (Table 8) that respondents had medium level of economic motivation; however 22.72 per cent and 20.90 per cent of the respondents were low and high level of economic motivation respectively. The findings of the present study are in line with Chauhan and Patel (2003), Jadhav (2009), Sharma et.al. (2014) and Wadekar (2016) ${ }^{[5,8,20,15]}$.

\section{Correlation and relationship of entrepreneurial behaviour} with personal and socio-economic characters of sugarcane juice centre owners

Innovativeness, achievement motivation, decision making ability, risk orientation and economic motivation are five basic functions of entrepreneurial behaviour was taken up as a components. The summation of scores of all these five components constituted the entrepreneurial behaviour score of the respondents.

The independent variables, viz., education, family size, occupation, annual income, marketing behaviour, source of information have positive and significant correlation with their entrepreneurial behaviour. (Table 9). That means with the increase in variables there will be an increase in the entrepreneurial behaviour of sugarcane juice centre owners. The independent variables age, land holding and area under crop has non-significant relationship with entrepreneurial behaviour (Table 9).The findings of the present study are in accordance with Jadhav (2009), Ghube (2014), Keisham (2016) and Wadekar (2016) ${ }^{[7,10,8,10]}$.

Land holding and area under crop was negative and nonsignificant at 0.05 level of probability. This might be due to the fact that land holding and area under crop of sugarcane juice centre owners was the not major mean of their livelihood. Hence, irrespective of their land holding and area under crop they tried to get more economic return. Present findings are in conformity with the findings of Kotadiya (2006), Wadekar (2016) ${ }^{[20,11]}$.

Table 9: Relationship between the profile of sugarcane juice centre owners with their entrepreneurial behaviour

\begin{tabular}{|c|c|c|}
\hline Sr. No. & Components & Correlation Coefficient (r) \\
\hline 1 & Age & $0.0839^{\mathrm{NS}}$ \\
\hline 2 & Education & $0.2129^{*}$ \\
\hline 3 & Family size & $0.1947^{*}$ \\
\hline 4 & Land holding & $-0.1165^{\mathrm{NS}}$ \\
\hline 5 & Occupation & $0.1925^{*}$ \\
\hline 6 & Annual income & $0.1880^{*}$ \\
\hline 7 & Marketing behaviour & $0.2066^{*}$ \\
\hline 8 & Area under sugarcane & $-0.07861^{\mathrm{NS}}$ \\
\hline 9 & Sources of information & $0.2542^{* *}$ \\
\hline
\end{tabular}

$*=$ Significant at 0.05 level of probability $* *=$ Highly significant at 0.01 level of probability NS $=$ Non-significant

\section{Conclusion}

The study has clearly shown that majority of the sugarcane juice centre owners belongs to medium level of entrepreneurial behaviour category. Hence, special consideration is required to enhance entrepreneurship. The medium level of major dimensions like innovativeness, achievement motivation, decision making ability, risk orientation and economic motivation of sugarcane juice centre owners together reflected the reason behind the medium entrepreneurial behaviour.

\section{References}

1. Bhagyalaxmi K, Gopalkrishna RV, Sundarshan RM. Profile of the rural women micro entrepreneurs. Journal of Research., Achairya N.G. Ranga Agricultural University, Hyderabad. 2003; 31(4): 51-54.

2. Bourah R, Borua S, Deka CR, Borah D. Entrepreneurial behaviour of Tribal Winter Vegetable Growers in Jorhat District of Assam. Indian Research Journal of Extension Education. 2015; 15(1):65-69.

3. Chandrapaul K. A study on Entrepreneurial Behaviour of Vegetable Growers in Krishna district of Andhra Pradesh. M.Sc. (Agril.) Thesis. Achairya N.G. Ranga Agricultural University, Hyderabad, 1998.

4. Choudhari RKS. A study an entrepreneurial behaviour of Potato growers in Malwa Region of Madhya Pradesh. M.Sc (Agril.). Thesis, Jawaharlal Nehru Krishi Vishwa Vidyalaya, 2006.

5. Chauhan NB, Patel RC. Entrepreneurial uniqueness of poultry entrepreneurs.Rural India. 2003; 66(12):236-239.

6. Daya R, Chaudhary KP. Socio-economical and Psychological characteristics of women entrepreneurs. 
Technofame- A Journal of Multidisciplinary Advance Research. 2012; 2(1):67-73.

7. Ghube GD. Entrepreneurial behaviour of pomogranate growers. M.Sc. (Agril.) Thesis Dr. Panjabrao Deshmukh Krishi Vidyapeeth Akola (M.S), 2014.

8. Jadhav HA. Entrepreneurial behaviour of floriculture growers of Mavaltahsil of Pune. M. Sc. (Agril.) Thesis Mahatma Phule Krishi. Vidyapeeth, Rahuri. (M.S), 2009.

9. Jayarani L, Singh MK, Chaudhary KP, Ram D. Entrepreneurship Behaviour of Women Entrepreneurs in Imphal of Manipur. Indian Research Journal of Extension Education. 2013; 13(2):31-35.

10. Keisham BS. Entrepreneurial behaviour of women entrepreneurs of IMA market. M. Sc. (Agril.) Thesis Mahatma Phule Krishi. Vidyapeeth., Rahuri. (M.S), 2016.

11. Kotadiya DG. Impact of integrated horticultural development programme in Junagadh district of Gujrat. Ph.D. Thesis Junagadh Agricultural University, Junagadh, 2006.

12. Kumar S, Gyanendra S, Yadav VK. Factors influencing entrepreneurial behaviour of vegetable growers. Indian Research Journal of Extension Education, 2013, 13(1).

13. Nagesh B, Halakatti SV, Hanchinal SN. Study on Entrepreneurial behaviour of pomegranate growers. Agriculture update. 2011; 6(3\&4):122-125.

14. Sapam S. A Study on the Entrepreneurial Behaviour of Vegetable Growers in Bishnupur District of Manipur. M.Sc. (Agril.) Thesis, Department of Extension Education, Central Agricultural University, Imphal, 2009.

15. Sharma A, Venyo V, Chauhan J. Entrepremeurial behaviour of potato growers in kohima district of Nagaland. Indian Research Journal of Extension Education. 2014; 14 (2): 82-86.

16. Suresh Reddy J. Entrepreneurship Concept and Development. Third Concept. 2004; 17(203):39-42.

17. Supe SV. Factors related to different degrees of rationality in decision making among farmers. $\mathrm{PhD}$. Thesis. Division of Agricultural. Extension Indian Agricultural Research Institute, New Delhi, 1969.

18. Shete KS. Study of technical gap in Chrysanthemum cultivation from Pandharpur Tahsil of Solapur district. M.Sc. (Agri.) Thesis, Mahatma Phule Krishi.Vidyapeeth., Rahuri. (M.S), 2008.

19. Thakare AK. Entrereneurial behaviour of floriculturist M.Sc. (Agri.) Thesis, Dr. Panjabrao Deshmukh Krishi Vidyapeeth Akola (M.S), 2013.

20. Wadekar AR. Entrepreneurial attributes of nursery growers. M.Sc. Thesis Dr. Panjabrao Deshmukh Krishi Vidyapeeth Akola (M.S), 2016. 